\title{
Technology transfer strategy for women in coffee livestock integration as climate-smart agriculture practice
}

\author{
Suci Wulandari ${ }^{1, *}$, and Fadjry Djufry ${ }^{2}$ \\ ${ }^{1}$ Indonesian Center for Estate Crops Research and Development, Bogor, Indonesia \\ ${ }^{2}$ Indonesian Agency for Agriculture Research and Development, Jakarta, Indonesia
}

\begin{abstract}
The Integrated Crop Livestock Systems (ICLS) is considered an important strategy to cope with climate change issues in coffee plantations. However, the involvement of women in the coffee livestock integration system is still limited. This condition is related to women's limited knowledge and technical capacity because there is no technology transfer model based on the requirements and needs of women. The purpose of this paper is to identify problems related to women's participation and formulate technology transfer strategies to increase women's participation in coffee livestock integration as a Climate-Smart Agriculture (CSA) practice. The research was conducted in Bandung Regency, West Java, as Indonesia's Arabica coffee development center. Data analysis was performed using descriptive statistics and Interpretive Structural Modeling (ISM). The role of women in management and decision-making in the development of coffee livestock is relatively low. Their involvement is still complementary, lacking initiative and limited participation due to internal and external issues. The strategies are related to three main areas: knowledge development, skill development, and technology utilization. The program derived from the strategies is expected to develop women's capacity both individually and in groups.
\end{abstract}

\section{Introduction}

Climate-Smart Agriculture (CSA) is an approach to transforming agriculture affected by climate change towards sustainable agriculture. This approach aims to increase productivity, increase resilience (adaptation), reduce GHGs (mitigation) where possible, and improve the achievement of national food security and development goals [1]. Coffee is very dependent on temperature and rainfall, so it is vulnerable to climate change [2]. CSA is part of sustainable agriculture, which is an essential issue in coffee plantations [3].

As a CSA practice, the Integrated Crops Livestock System (ICLS) is implemented in the coffee commodity system [4]. ICLS has the potential benefit of reducing the environmental impacts associated with agriculture and improving farmers' livelihoods [5]. ICLS can increase productivity by decreasing production costs and creating profitable

* Corresponding author: suciwulandari@pertanian.go.id 
systems. ICLS can increase production and product quality [6]. Socially, increasing farmers' income will encourage business expansion and increase demand for agricultural labor [7].

The contribution of women in ICLS in Indonesia has not been optimal. Women's involvement in coffee livestock integration is still limited in terms of the volume of work and the depth of the participation. On the other hand, the implementation of integration provides significant additional jobs for farmer households, which, if not supported by the involvement of women, will not run optimally.

The involvement of women in the dissemination and adoption of technology is limited due to various obstacles faced [8] [9]. Various problems are found, such as limited knowledge, skills, and technology acquisition. On the other hand, technology plays an essential role in the practice of CSA. Therefore, a strategy is needed to encourage increased involvement of women with adequate technology support through technology transfer. The purposes of this study are to identify problems related to women's participation and formulate technology transfer strategies to increase women's participation in the coffee livestock integration as a CSA practice.

\section{Research Method}

\subsection{Time and Location}

The research was conducted in October-November 2020 in Bandung Regency, West Java Province, Indonesia (Figure 1). Bandung Regency is one of the Arabica coffee centers which is also developing the integration of livestock coffee.

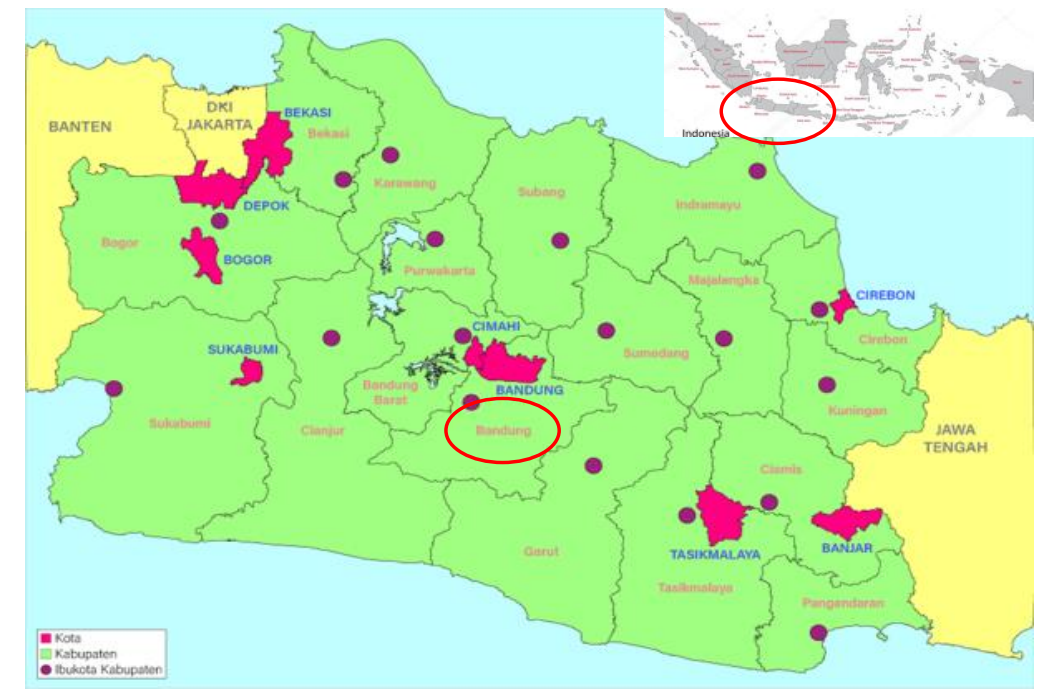

Fig 1. Research Location

\subsection{Data Collecting Method}

Data was collected through a survey of 41 coffee farmers' households. Respondents were selected using a purposive sampling technique based on the ownership of the coffee plantation. Data were collected through interviews using a questionnaire and field 
observations. The involvement of women in the agricultural sector can be divided into home-based activities or paid agricultural work [10]. The focus of the study was women's participation in home-based agriculture. Questions include coffee plantation profile, farmers' characteristics, and problems on technology-related women participation.

\subsection{Data Analysis}

Data analysis was performed using descriptive statistics. Descriptive statistics is data analysis by describing data [11]. Descriptive statistics are methods of collection and presentation of data to provide useful information. Descriptive statistics are broken down into measures of central tendency and measures of variability. Measures of central tendency include the mean, median, and mode, while measures of variability include standard deviation, variance, minimum and maximum variables.

Strategy analysis was performed using Interpretive Structural Modeling (ISM). ISM is an assessment process in which structural models are generated to capture complex matters of a system through carefully designed patterns using graphics and sentences [12]. The stages of ISM analysis consist of: identifying system elements, analyzing contextual relationships, compiling a Structural Self Interaction Matrix (SSIM), and compiling a Reachability Matrix (RM) [13].

SSIM is composed of elements of respondents' perceptions of the elements of the intended destination. Four symbols are used to represent the type of relationship that exists between two elements. Where ' $\mathrm{V}$ ' indicates the relationship of the element Ei to $\mathrm{Ej}$, not vice versa, ' $A$ ' indicates the relationship of the element $\mathrm{Ej}$ to $\mathrm{Ei}$, not vice versa, ' $\mathrm{X}$ ' indicates the relationship between $\mathrm{Ei}$ and $\mathrm{Ej}$, can be vice versa, and ' $\mathrm{O}$ ' indicates that $\mathrm{Ei}$ and $\mathrm{Ej}$ are not related. RM can be arranged by converting the SSIM symbols into a binary matrix.

From the ISM approach, the classification of elements into four sectors is obtained, namely: (1) Autonomic, elements that have weak drivers and weak dependents, which means they are slightly related to the system, (2) Dependent, elements that have weak drivers and strong dependents, are dependent elements. (3) Linkages, elements that have strong drivers and strong dependents, are sensitive and unstable elements, and (4) Independent, elements that have strong drivers and weak dependents, are the most powerful elements or key elements.

\section{Result and Discussion}

\subsection{Farmer Characteristic and Women Participation Description}

Arabica coffee cultivation is usually at an altitude of 800-2000 $\mathrm{m}$ asl with a temperature of $15-25^{\circ} \mathrm{C}$ and rainfall of around 1750-3000 mm/year. The development of Arabica coffee plants in the highlands requires a conservation system that supports environmental sustainability. The regional government initiates coffee development in Bandung Regency to improve the upstream area of the Citarum Watershed. Meanwhile, coffee livestock integration began with an environmentally friendly program to develop a sustainable agricultural system.

The average coffee plantation area of respondent farmers is $0.97 \mathrm{ha}$, with the lowest area being 0.14 ha and the highest area being 5 ha (Table 1). The wide variation between respondents is relatively large, so the intensity of coffee plantation management is not the same. This can be seen from the variation in the number of coffee trees that vary per unit area. The average number of trees owned is 1733 trees. 
Table 1. Coffee farming and farmers' characteristic

\begin{tabular}{|l|r|r|r|r|}
\hline & \multicolumn{1}{|c|}{ Min } & \multicolumn{1}{c|}{ Max } & \multicolumn{1}{c|}{ Mean } & \multicolumn{1}{c|}{$\begin{array}{c}\text { Std. } \\
\text { Deviation }\end{array}$} \\
\hline Land (hectare) & 0.14 & 5.00 & 0.9744 & 0.87507 \\
\hline Number of Coffee Trees (trees) & 95 & 12500 & 1733.41 & 2116.798 \\
\hline Coffee Farming Experience (years) & 2 & 20 & 9.13 & 4.601 \\
\hline Cattle Management Experience (years) & 2 & 49 & 17.91 & 13.377 \\
\hline
\end{tabular}

The experience of livestock management is relatively longer than coffee cultivation. Some farmers already have sheep that are kept around the house. The number of livestock owned is still limited, 2-5 sheep. Most farmers have not integrated their agricultural activities, so there is no link in product utilization between coffee plantations and sheep farming.

The role of women in the coffee farming system is still limited. In cultivation activities, even $58.54 \%$ of women were never involved (Figure 2). The same is valid for fertilizing and harvesting activities. Women are relatively much involved in pest disease management and post-harvest activities.

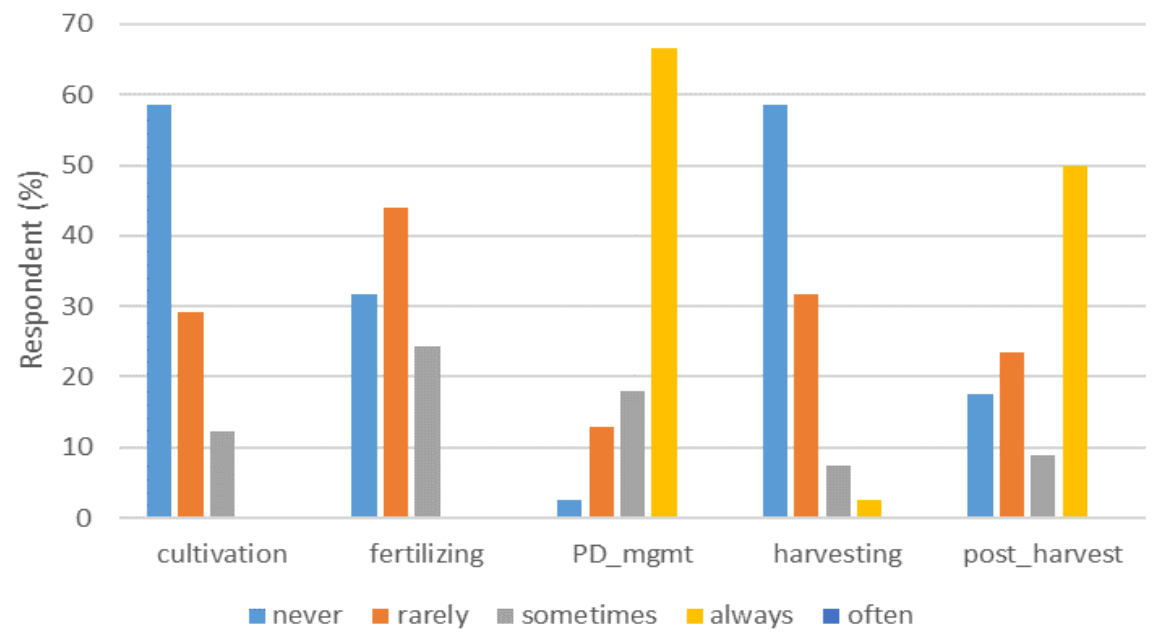

Fig 2. Women participation in the coffee farming system

In livestock business activities, women are relatively limited to being involved in livestock management, of which $68.97 \%$ are rarely involved (figure 3). More involvement is seen in utilizing cattle wase for organic fertilizer (65\% always) and animal feed management ( $52.50 \%$ always).

Women's participation is still complementary. Involvement occurs in physical activity, which is a routine activity of farmers. Women have not been significantly involved in the decision-making process of the farming system. The management and plans for developing agricultural activities are still held by the head of the farmer's household.

Regarding the application of CSA, technology plays an important role in its application [14]. Various technologies are available to support the application of CSA in coffee plantations. CSA can be applied in the integrated water, soil, and ecosystems management at the landscape scale [15]. Cultivation techniques can be a preventive or mitigation measure in dealing with climate variability or global warming in coffee plants. Therefore, technology in plantation management systems becomes demanded. 


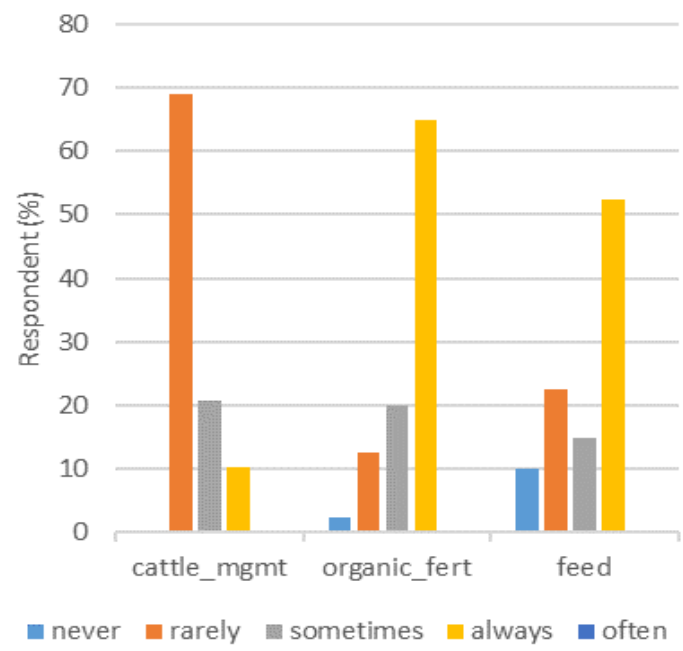

Fig 3. Women participation in cattle management

\subsection{Problems Identification on technology-related of Women Participation}

The limited involvement of women in coffee livestock integration is also marked by their low technical and managerial abilities. This can be seen from the opinions of respondents who stated that they agreed related to insufficient knowledge (41.5\% agree and $4.9 \%$ strongly agree), low technology acquisition (56.1\% agree and $4.9 \%$ strongly agree), and limited skills in managing farming systems (48\% agree). (Figure 4). This condition is closely related to technology dissemination.

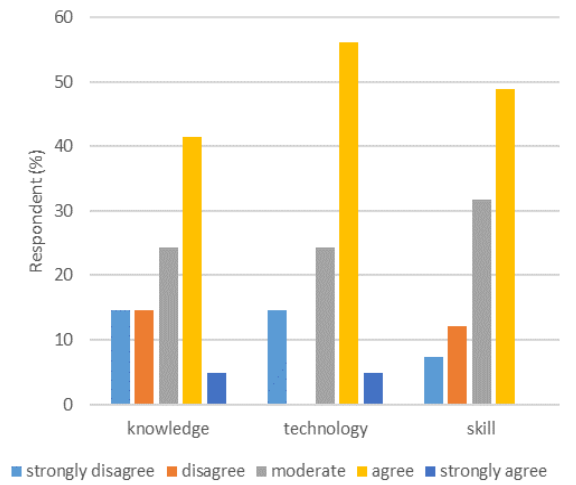

Fig 4. Assessment of problems in coffee livestock integration management

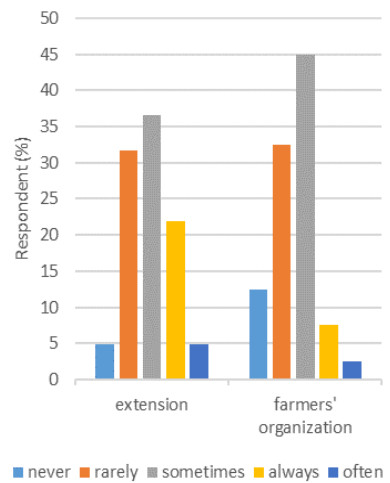

Fig 5. Women involvement in the extension and farmers' organization

Dissemination is the process of communicating new information, ideas, or practices. Technology transfer and diffusion are two aspects of technology dissemination as transmitting innovation from source to recipient. The development of dissemination requires a communication strategy that includes selecting media and media combinations, developing messages, and selecting the right approach to foster target participation. In technological diffusion, the source is not necessarily aware of who the recipient is. 
Technology transfer involves communication between a specific source and a specific recipient or group of recipients.

The transfer of information, knowledge, and technology occurs through extension activities and exchanges between farmers groups. However, these activities are dominated by the heads of farmer households and only involve a minimal number of women. The participation of women in the activities of farmer groups and organizations is still low. Men usually carry out involvement as the head of the household. The data shows that the number of women involved is relatively low, namely $21.95 \%$ always and $4.88 \%$ often for extension activities and $7.50 \%$ always and $2.50 \%$ often for farmer group activities (Figure 5 ). Some of the problems of women's participation in agricultural activities related to the transfer and use of technology consist of problems from internal and external aspects (Table 2).

Table 2. Problems identification on technology-related of women participation in coffee livestock integration

\begin{tabular}{|c|c|}
\hline Aspect & Problems \\
\hline \multirow[t]{6}{*}{ Internal } & 1. Limited time availability for agricultural extension activities \\
\hline & 2. Lack of resource availability for agricultural dissemination participation \\
\hline & $\begin{array}{l}\text { 3. Low motivation and self-confidence to participate in technology dissemination } \\
\text { activities }\end{array}$ \\
\hline & $\begin{array}{l}\text { 4. Limited access to information sources on the formal system of dissemination and } \\
\text { extension }\end{array}$ \\
\hline & 5. Lack of women focus and feedback on technology dissemination activities \\
\hline & 6. Limited knowledge and skills in finding and utilizing agriculture information \\
\hline \multirow[t]{5}{*}{ External } & 1. Inadequate operating resources \\
\hline & 2. Inadequate financial support \\
\hline & 3. Weak research-extension linkages for the sensitive gender issue \\
\hline & 4. $\quad$ Limited technology transfer model for women \\
\hline & 5. Stagnation in women's group developing and increasing capacity building \\
\hline
\end{tabular}

Internal problems related to the low motivation and self-confidence to participate in technology dissemination activities. The condition of women who have domestic tasks so that they have free time and have limited resources. Women also have limited access to the formal system of dissemination and extension activities. Domestic household activities can cause a lack of women's focus and feedback on agricultural activities. In addition, women do not have the knowledge and skills in finding and utilizing agricultural information.

The existing technology transfer is based on men's profile as heads of farmer households. Therefore, time, place, method, and material align with men's characteristics and availability. This condition is inseparable from the limited operating resources and financial support. Most agricultural researchers do not give attention to gender analysis in technology development. Regarding technology, research-extension linkages for gendersensitive issues are weak, so the technology produced and the technology diffusion model built are generic.

The transfer of information, knowledge, and technology between farmers is usually through farmer groups, which men dominate. Extension methods have moved towards more participatory approaches, and increasingly based on communication technologies. However, some national systems are still gender-insensitive. From the institutional side, there is stagnation in women's group developing and increasing capacity building. Farmers' groups effectively disseminate technologies, build a sense of shared purpose, and enable cooperative action in climate-smart agriculture applications. 


\subsection{Technology Transfer Strategies to Optimize Women Participation}

Technology covers three main areas, namely knowledge, skills, and equipment [16]. The design of technology transfer is related to these three main areas. Technology transfer strategy is not directly addressed to how technology is applied. Therefore, gradually technology transfer will be related to the development process of (1) awareness, (2) understanding, (3) support and favorability, (4) involvement, and (5) commitment and action.

Women's involvement in Bandung Regency in coffee livestock integration is still very limited, even though women are potential resources to increase added value and build sustainable production. Additional work due to the implementation of coffee livestock integration can be carried out effectively if women are provided with adequate knowledge, skills, and use of technology. In addition, a women's working group with an entrepreneurial perspective was also built. Iteratively, the strategy will begin with knowledge development, then skill development, and technology utilization. Various programs are designed as part of the implementation of the strategy.

The strategy knowledge development program for increasing women's involvement in technology transfer consists of 7 programs (Table 3). Analysis using ISM shows that the development of communication channels with extension workers and research institutes, Training on introduction and utilization of internet-based information sources, and strengthening farmers and women's groups are program elements with strong drivers and weak dependents. These programs are the most powerful or key programs (Figure 6).

Table 3. Knowledge development program for increasing women involvement in technology transfer

\begin{tabular}{|l|l|l|l|}
\hline Strategy & No & Objectives & Program \\
\hline $\begin{array}{l}\text { Knowledge } \\
\text { Development }\end{array}$ & 1. & $\begin{array}{l}\text { Improved access to information } \\
\text { sources }\end{array}$ & $\begin{array}{l}\text { Development of communication } \\
\text { channels with extension workers and } \\
\text { research institutes }\end{array}$ \\
\cline { 2 - 4 } & 2. & $\begin{array}{l}\text { Increased the ability to use } \\
\text { internet-based information sources }\end{array}$ & $\begin{array}{l}\text { Training on introduction and } \\
\text { utilization of internet-based } \\
\text { information sources }\end{array}$ \\
\cline { 2 - 5 } & 3. & $\begin{array}{l}\text { Increased sensitivity to climate } \\
\text { change }\end{array}$ & $\begin{array}{l}\text { Training on climate change and its } \\
\text { impact on coffee }\end{array}$ \\
\cline { 2 - 4 } & 4. & $\begin{array}{l}\text { Improved understanding of CSA } \\
\text { practices based on livestock coffee } \\
\text { integration }\end{array}$ & $\begin{array}{l}\text { Training on the integration of } \\
\text { livestock coffee as a CSA model }\end{array}$ \\
\cline { 2 - 4 } & 5. & $\begin{array}{l}\text { Improved technical knowledge of } \\
\text { coffee cultivation and livestock } \\
\text { management }\end{array}$ & $\begin{array}{l}\text { Plot demonstration of the application } \\
\text { of coffee cultivation and livestock } \\
\text { management }\end{array}$ \\
\cline { 2 - 4 } & 6. & $\begin{array}{l}\text { Increased knowledge of group } \\
\text { dynamics and organizational } \\
\text { management }\end{array}$ & $\begin{array}{l}\text { Strengthening of farmers and } \\
\text { women's groups }\end{array}$ \\
\cline { 2 - 4 } & 7. & $\begin{array}{l}\text { Increased risk knowledge on the } \\
\text { integration of coffee livestock and } \\
\text { risk management }\end{array}$ & $\begin{array}{l}\text { Pest Disease Management field } \\
\text { school }\end{array}$ \\
\hline
\end{tabular}




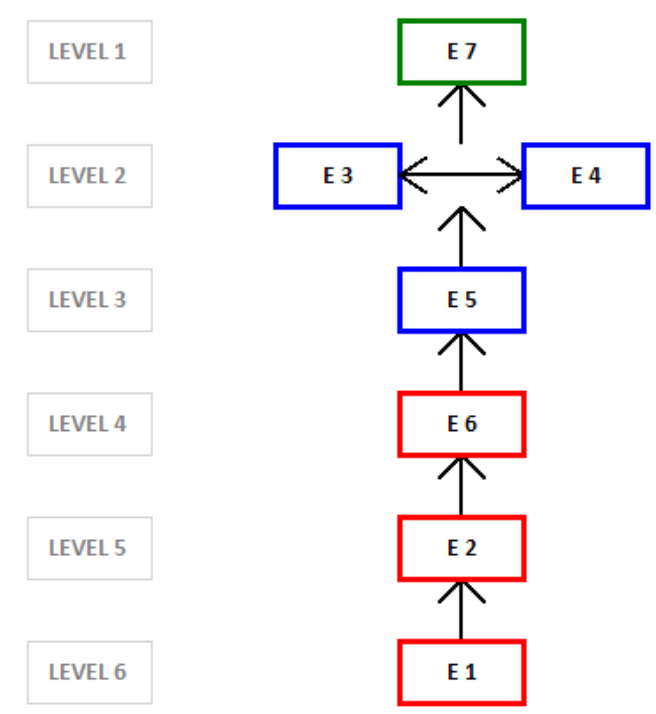

Fig 6. Structure of knowledge development program for increasing women involvement in technology transfer

Description: E1=Development of communication channels, E2=Training on introduction and utilization of internet-based, E3=Training on climate change and its impact on coffee, E4=Training on coffee livestock integration, E5 = Plot demonstration, E6= strengthening of farmers and women's groups, E7= Pest Disease Management field school

Skill development program for increasing women's involvement in technology transfer consists of 6 programs (Table 4). Analysis using ISM shows that Bio-entrepreneurship training and development of women's working groups and the provision of mentors are program elements with strong drivers and weak dependents. These programs are the most powerful or key programs (Figure 7).

Table 4. Skill development program for increasing women involvement in technology transfer

\begin{tabular}{|l|l|l|l|}
\hline Strategy & No & Objectives & Program \\
\hline $\begin{array}{l}\text { Skill } \\
\text { development }\end{array}$ & 1. & $\begin{array}{l}\text { Increased entrepreneurship in the } \\
\text { context of livestock coffee } \\
\text { integration }\end{array}$ & Bio-entrepreneurship training \\
\cline { 2 - 4 } & 2. & $\begin{array}{l}\text { Increased learning capacity with } \\
\text { continuous assistance }\end{array}$ & $\begin{array}{l}\text { Development of women's working } \\
\text { groups and provision of mentors }\end{array}$ \\
\cline { 2 - 4 } & 3. & $\begin{array}{l}\text { Improved GAP implementation } \\
\text { capability }\end{array}$ & $\begin{array}{l}\text { Organizing outreach activities } \\
\text { according to women's time and } \\
\text { resources }\end{array}$ \\
\cline { 2 - 4 } & 4. & Improved waste treatment capability & Waste treatment practices \\
\cline { 2 - 4 } & 5. & $\begin{array}{l}\text { Development of Product processing } \\
\text { capability and added value }\end{array}$ & $\begin{array}{l}\text { Product processing practices and } \\
\text { packaging techniques }\end{array}$ \\
\cline { 2 - 4 } & 6. & $\begin{array}{l}\text { Improved conflict management } \\
\text { capabilities }\end{array}$ & Conflict management training \\
\hline
\end{tabular}




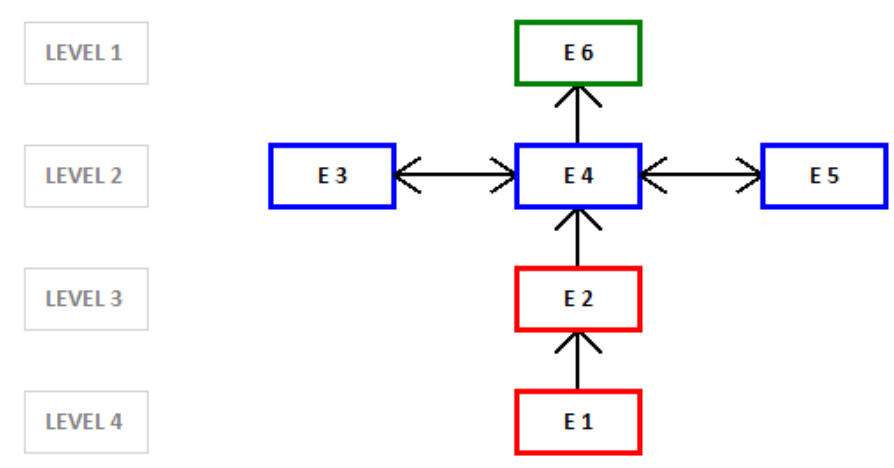

Fig 7. Structure of skill development program for increasing women involvement in technology transfer

Description: E1=Bio-entrepreneurship training, E2=Development of women's working groups and provision of mentors, E3=Organizing outreach activities according to women's time and resources, E4=Waste treatment practices, E5=Product processing practices, and packaging techniques, E6=Conflict management

Technology utilization program for increasing women's involvement in technology transfer consists of 6 programs (Table 5). Analysis using ISM shows that the development of an extension model following the conditions and resources of women and practice and assistance in using digital-based marketing technology are program elements with strong drivers and weak dependents. These programs are the most powerful or essential programs (Figure 8).

Table 5. Technology utilization program for increasing women involvement in technology transfer

\begin{tabular}{|l|l|l|l|}
\hline Strategy & No & Objectives & Program \\
\hline $\begin{array}{l}\text { Technology } \\
\text { utilization }\end{array}$ & 1. & $\begin{array}{l}\text { Participation in agricultural } \\
\text { extension }\end{array}$ & $\begin{array}{l}\text { Development of an extension model that } \\
\text { is following the conditions and resources } \\
\text { of women }\end{array}$ \\
\cline { 2 - 4 } & 2. & $\begin{array}{l}\text { Participation in field school } \\
\text { activities }\end{array}$ & $\begin{array}{l}\text { Development of a field school model that } \\
\text { is under the conditions and resources of } \\
\text { women }\end{array}$ \\
\cline { 2 - 4 } & 3. & $\begin{array}{l}\text { Access to the use of technology } \\
\text { for making organic fertilizers }\end{array}$ & Organic fertilizer processing practices \\
\cline { 2 - 4 } & 4. & $\begin{array}{l}\text { Access to the use of feed } \\
\text { processing technology }\end{array}$ & Feed production practices \\
\cline { 2 - 4 } & 5. & $\begin{array}{l}\text { Access to the use of coffee } \\
\text { processing technology and } \\
\text { coffee waste }\end{array}$ & $\begin{array}{l}\text { Coffee processing practices and coffee } \\
\text { waste management }\end{array}$ \\
\cline { 2 - 4 } & 6. & $\begin{array}{l}\text { Access the use of digital-based } \\
\text { marketing technology }\end{array}$ & $\begin{array}{l}\text { Digital-based marketing technology } \\
\text { application }\end{array}$ \\
\hline
\end{tabular}




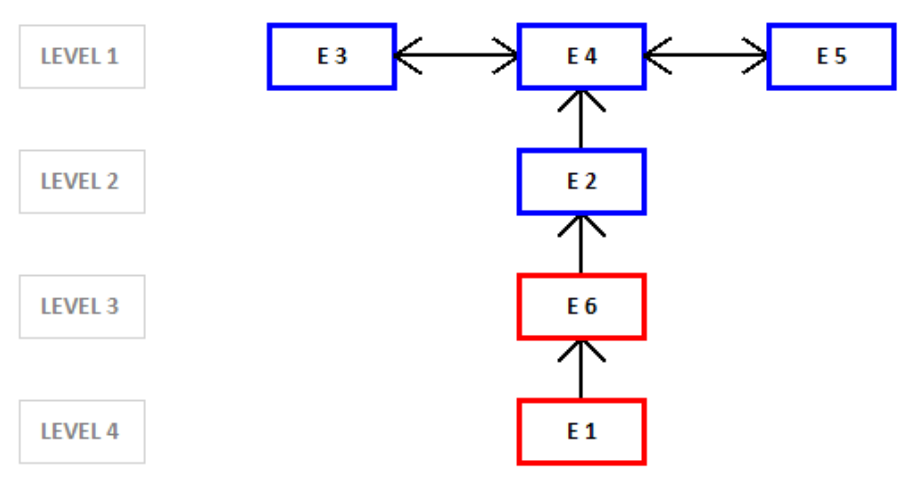

Fig 8. Structure of technology utilization program for increasing women involvement in technology transfer

Description: E1=Development of an extension model, E2=Development of a field school model, E3=Organic fertilizer processing practices, E4=Feed production practices, E5=Coffee processing practices and coffee waste management, E6=Digital-based marketing technology application

Implementing the strategy for increasing women's involvement in technology transfer is expected to increase women's involvement in coffee livestock integration effectively. The programmed women participation is expected to build the capacity of women both individually and in groups in a sustainable manner so that women's involvement programs are no longer trapped in the formalities of representation.

Given that the strategy and program for involving women is a medium-term agenda, its implementation requires a support system that involves other stakeholders. Specifically, the involvement of women in the agricultural sector will encourage increased production if it is also supported by women's access to credit, asset accumulation, and community leadership [17]. By increasing the participation of women in coffee livestock integration, the performance of the application of CSA practices at the farmer level will increase, and an adaptive agricultural system to climate change will be built.

\section{Conclusion}

Coffee livestock integration as a Climate-Smart Agricultural practice opens up great opportunities for women's participation. The role of women in coffee cultivation and livestock management can be developed into a broader role in the form of resource managers and agricultural business structure. Additional work as a consequence of the implementation of coffee livestock integration can be carried out effectively if women are provided with adequate knowledge, skills, and use of technology. In addition, a women's working group with an entrepreneurial perspective was also necessary to develop.

Iteratively, the strategy will begin with knowledge development, then skill development, and technology utilization. Various programs are designed to implement the strategy in developing an effective system of work and management of activities. The performance is carried out iteratively on a medium-term time frame. In addition, a support system is needed in its implementation, which includes providing access to financial support, asset accumulation, and community leadership. 


\section{References}

1. FAO, Climate Smart Agriculture Sourcebook (2013).

2. Y. Pham, K. Reardon-Smith, S. Mushtaq, and G. Cockfield, Clim. Change 156, 609 (2019).

3. D. Reay, in Clim. Food (2019), pp. 93-104.

4. F. Djufry and S. Wulandari, IOP Conf. Ser. Earth Environ. Sci. 653, 1 (2021).

5. U. Sekaran, L. Lai, D. A. N. Ussiri, S. Kumar, and S. Clay, J. Agric. Food Res. 5, 100190 (2021).

6. A. B. Santoso, J. Ilmu Pertan. Indones. 22, 108 (2017).

7. R. D. Garrett, M. T. Niles, J. D. B. Gil, A. Gaudin, R. Chaplin-Kramer, A. Assmann, T. S. Assmann, K. Brewer, P. C. de Faccio Carvalho, O. Cortner, R. Dynes, K. Garbach, E. Kebreab, N. Mueller, C. Peterson, J. C. Reis, V. Snow, and J. Valentim, Agric. Syst. 155, 136 (2017).

8. S. E. Sanyang, T.-C. Kao, and W.-C. Huang, World J. Agric. Sci. 5, 169 (2009).

9. U. Ogechi, African J. Gend. Dev. 3, 135 (2016).

10. UN Women, Women's Participation in the Agricultural Sector, Rural and Community Life (Amman, 2018).

11. P. Mishra, C. M. Pandey, U. Singh, A. Gupta, C. Sahu, and A. Keshri, Ann. Card. Anaesth. 67 (22019).

12. R. Dubey, A. Gunasekaran, Sushil, and T. Singh, Int. J. Syst. Sci. Oper. Logist. 2, 231 (2015).

13. R. Attri, N. Dev, and V. Sharma, Res. J. Manag. Sci. 2319, 1171 (2013).

14. B. K. Kurgat, C. Lamanna, A. Kimaro, N. Namoi, L. Manda, and T. S. Rosenstock, Front. Sustain. Food Syst. 4, (2020).

15. A. Sullivan, A. Mumba, S. Hachigonta, M. Connolly, and L. M. Sibanda, Climate Smart Agriculture: More Than Technologies Are Needed to Move Smallholder Farmers Toward Resilient and Sustainable Livelihoods (2012).

16. L. I. Le Grange and A. J. Buys, South African J. Ind. Eng. 13, 81 (2012).

17. G. M. Diiro, G. Seymour, M. Kassie, G. Muricho, and B. W. Muriithi, PLoS One 13, 1 (2018). 